\title{
Article \\ Removal of Polystyrene Microplastics from Aqueous Solution Using the Metal-Organic Framework Material of ZIF-67
}

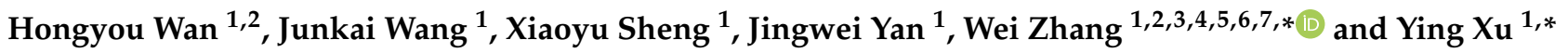 \\ 1 School of Ecology and Environment, Zhengzhou University, 100 Kexue Avenue, Zhengzhou 450001, China; \\ hywan@zzu.edu.cn (H.W.); 13014502079@163.com (J.W.); sxy15670527525@163.com (X.S.); \\ yanjingweide@163.com (J.Y.) \\ 2 Research Centre of Engineering and Technology for Synergetic Control of Environmental Pollution and \\ Carbon Emissions of Henan Province, Zhengzhou 450001, China \\ 3 Henan International Joint Laboratory of Water Cycle Simulation and Environmental Protection, \\ Zhengzhou 450001, China \\ 4 Zhengzhou Key Laboratory of Water Resource and Environment, Zhengzhou 450001, China \\ 5 Yellow River Institute for Ecological Protection and Regional Coordination Development, \\ Zhengzhou University, Zhengzhou 450001, China \\ 6 Henan Key Laboratory of Water Pollution Control and Rehabilitation Technology, \\ Pingdingshan 467036, China \\ 7 Henan Key Laboratory of Water Resources Conservation and Intensive Utilization in the Yellow River Basin, \\ Zhengzhou 450001, China \\ * Correspondence: zhangwei88@zzu.edu.cn (W.Z.); xuying@zzu.edu.cn (Y.X.)
}

check for updates

Citation: Wan, H.; Wang, J.; Sheng,

X.; Yan, J.; Zhang, W.; Xu, Y. Removal of Polystyrene Microplastics from Aqueous Solution Using the Metal-Organic Framework Material of ZIF-67. Toxics 2022, 10, 70.

https://doi.org/10.3390/ toxics 10020070

Academic Editors: Fabrizio Olivito and Pravin Jagdale

Received: 3 January 2022

Accepted: 29 January 2022

Published: 4 February 2022

Publisher's Note: MDPI stays neutral with regard to jurisdictional claims in published maps and institutional affiliations.

Copyright: (C) 2022 by the authors. Licensee MDPI, Basel, Switzerland. This article is an open access article distributed under the terms and conditions of the Creative Commons Attribution (CC BY) license (https:// creativecommons.org/licenses/by/ $4.0 /)$.

\begin{abstract}
Due to the continuous and adverse effects of microplastics on the environment, an increasing number of studies have begun to focus on their migration patterns and removal from aquatic environments. Herein, our study innovatively evaluated the ability of the capacity of ZIF-67, a novel metal-organic framework (MOF) material, to adsorb polystyrene (PS) microplastics (MPs) from aqueous solutions, aiming to explore the potential of MOF materials to remove MPs from wastewater. The adsorption ratio of PSMPs $(5 \mathrm{mg} / \mathrm{L}, 30 \mathrm{~mL})$ by ZIF- 67 reached up to $92.1 \%$, and the PSMP adsorption equilibrium was achieved within $20 \mathrm{~min}$ at $298 \mathrm{~K}$. The adsorption of PSMPs would be favored at a $\mathrm{pH}$ of 8 , a PSMPs solution concentration of $5 \mathrm{mg} / \mathrm{L}$, and a temperature of 298 K. Further analyses demonstrated that hydrogen bond interactions, $\pi-\pi$ stacking, and electrostatic interactions played a crucial role in the adsorption of PSMPs by ZIF-67 in aqueous solutions. Our findings thus provide insight into novel methods to remove MPs from acidic and weakly alkaline aquatic environments and wastewater.
\end{abstract}

Keywords: microplastics; MOF material; ZIF-67; adsorption; water environment

\section{Introduction}

Worldwide plastic production reached 368 million tons in 2019, and these outputs are projected to reach 3.3 billion tons by 2050 [1]. These increases in plastic production and consumption will inevitably lead to increases in the discharge of plastic waste. In natural water or soil environments, microplastics (MPs, with size ranging from $1 \mu \mathrm{m}$ to $5 \mathrm{~mm}$ ) are generated from the degradation of plastic products through natural processes such as UV photodegradation, mechanical degradation, and hydrolysis [2-5]. MPs have become extremely conspicuous and have already been detected in personal care products, food (e.g., drinking water, milk, and table salt), and baby products [6-9]. Additionally, MPs are known to adsorb many types of pollutants such as heavy metals, persistent organic pollutants (POPs), and chemical additives such as flame retardants and antioxidants [2,10-17], thus exacerbating their adverse effects on human and animal health [18-22]. For example, after ingesting microplastics, the marine invertebrates' digestive enzyme systems would be damaged, and even their reproductive system might be affected $[19,23]$. Furthermore, 
microplastics can accumulate in the human body and lead to obesity, cancer, and infertility $[8,24-26]$. As reported, microplastics have already been detected in wastewater in large amounts $(0.05 \pm 0.024 \mathrm{n} / \mathrm{L})$, including plastic particles, fibers, fragments, films, and granules $[27,28]$. Microplastics will inevitably discharge into the aquatic environment, and further affect the survival of animals, plants, and microorganisms [29,30]. Several methods have been developed to remove MPs from wastewater, including filtration, coagulation, foam flotation, and magnetic separation [31-35]. However, these methods cannot efficiently remove smaller particle size plastics $(<10 \mu \mathrm{m})$. Other studies have employed chitin sponge or biochar to adsorb MPs from aquatic environments [36,37]. Nevertheless, additional research is still required to identify novel methods and mechanisms to remove MPs $(<10 \mu \mathrm{m})$ from water environments.

Metal-organic framework (MOF) materials have recently garnered increasing attention due to their applicability in water remediation [38]. Among these materials, zeolitic imidazolate frameworks (ZIF) are particularly promising, owing to their many advantages $[11,39]$. Specifically, these materials can be easily prepared, and possess a large specific surface area, stable structure, and large adsorption capacity [40-42]. ZIF-67 is a porous material, with $\mathrm{CO}^{2+}$ and 2-methylimidazole acting as the central metal ion and organic ligand, respectively [43,44]. Previous research has demonstrated that ZIF-67 could effectively adsorb and remove pollutants (e.g., organic pollutants, heavy metals, and antibiotics) from water through interface forces, including hydrogen bonding, electrostatic action, and $\pi-\pi$ stacking [39,45-47]. However, very few studies have focused on the capacity of ZIF-67 to remove PSMPs from aqueous solutions.

Our study thus evaluated the PSMPs $(<10 \mu \mathrm{m})$ removal performance of ZIF-67 in aqueous solutions. Specifically, this study assessed the key effects of ZIF-67 dose, contact time, $\mathrm{pH}$, contact temperature, and PSMPs concentration on the adsorption process to explore the PSMP removal capacity of ZIF-67 in aqueous solution, as well as its potential adsorption mechanisms. We hypothesized that ZIF-67 could effectively adsorb and remove MPs from water through hydrogen bonding, electrostatic action, and $\pi-\pi$ stacking, which could serve as the basis for novel strategies to treat MP contaminated wastewater.

\section{Materials and Methods}

\subsection{Chemicals and Materials}

Fluorescent PSMPs (with average diameter of $1.0 \mu \mathrm{m}, 1 \% w / v$ ) were purchased from the Tianjin Beisiline Chromtech Research Center, (Tianjin, China). The fluorescent PSMPs stock solution was diluted using deionized water, then treated with an ultrasonic device (KQ-100DE, KunShan Ultrasonic Instruments Co., Ltd., Jiangsu, China) for 10 min at $100 \mathrm{~W}$ and $20 \mathrm{kHz}$ to obtain the desired PS concentrations $(5,10,15,20,25,30,40$, and $50 \mathrm{mg} / \mathrm{L}$ ). The ZIF-67 used in this investigation was prepared through a high-throughput production method [47]. The concentrated hydrochloric acid $(\mathrm{HCl})$ and sodium hydroxide $(\mathrm{NaOH})$ used in this experiment were of analytical grade and were supplied by Tianjin Hengxing chemical reagent Co., Ltd., Tianjin, China.

\subsection{Material Characterization}

A Zetasizer Nano ZS system (Malvern Panalytical Co., Ltd., Malvern, UK) was used to measure the mean hydrodynamic diameters and Zeta potentials of ZIF-67 and PSMP particles at a 3-12 pH range. Fourier transform infrared spectroscopy (FTIR, tensor 27, Brooke, Germany) was applied to characterize the possible functional groups in PSMP and ZIF-67 (before and after plastic adsorption) at a $500-4000 \mathrm{~cm}^{-1}$ range. The surface morphologies of PSMPs and ZIF-67 (before and after adsorption) were observed via scanning electron microscopy (SEM, Zeiss GmbH, Oberkochen, Germany). Fluorescence images of PSMPs and ZIF-67 (before and after adsorption of plastics) were observed using a fluorescence microscope (NE620-FL, Ningbo Yongxin Optical Co., Ltd., Zhejiang, China). 


\subsection{Adsorption of PSMPs by ZIF-67}

In the adsorption process, the ZIF-67 (with a constant mass) and PSMPs solutions (with different concentrations, $30 \mathrm{~mL}$ ) were added into a conical glass flask $(100 \mathrm{~mL})$, then placed in an air bath oscillator (ZYC-1189L, Shanghai Zhetu scientific instrument Co., Ltd., Shanghai, China) at room temperature $\left(25^{\circ} \mathrm{C}\right)$ with a shaking speed of $150 \mathrm{rpm}$. Upon the completion of the shaking process, the concentration of PSMPs in the solution supernatant was determined with a fluorescence spectrometer (NF-900, Thermo Fisher Scientific, Seoul, Korea), with a scanning speed of $600 \mathrm{~nm} / \mathrm{min}$; the voltage of the photomultiplier tube was $400 \mathrm{~V}$. The emission spectra were recorded at a $400-500 \mathrm{~nm}$ wavelength range after excitation at $468 \mathrm{~nm}$.

All experiments were conducted in triplicate using independent samples. Conical glass flasks with a PSMP-only solution (without ZIF-67 addition) were set as the control group.

\subsubsection{Effect of ZIF-67 Dose and PSMP Concentration}

To investigate the effect of the ZIF-67 dose on PSMP adsorption, various amounts of ZIF-67 (0.1, 0.2, 0.3, 0.4, 0.5, and $0.6 \mathrm{~g} / \mathrm{L})$ were added into the PS solution $(5 \mathrm{mg} / \mathrm{L}$, $30 \mathrm{~mL}$ ) in a $150 \mathrm{~mL}$ Erlenmeyer flask. The contact time and temperature were $20 \mathrm{~min}$ and 298 K, respectively.

The PSMP adsorption rates of ZIF-67 $(0.4 \mathrm{~g} / \mathrm{L})$ were then measured in response to various PSMP concentrations $(5,10,15,20,25,30,40$, and $50 \mathrm{mg} / \mathrm{L})$. The contact time and temperature were $20 \mathrm{~min}$ and $298 \mathrm{~K}$, respectively.

\subsubsection{Effect of Contact Time}

The effect of reaction time on PSMP adsorption performance was assessed at different contact times $(1,5,10,20,30,40,50$, and $60 \mathrm{~min})$ at a constant $0.4 \mathrm{~g} / \mathrm{L}$ ZIF-67 dose. The volume of the PSMP solution ( $5 \mathrm{mg} / \mathrm{L}$ ) was $30 \mathrm{~mL}$, with a contact temperature of $298 \mathrm{~K}$.

\subsubsection{Effect of $\mathrm{pH}$ and Temperature}

The effect of $\mathrm{pH}$ on PSMP adsorption performance by ZIF-67 was investigated at a 3-12 $\mathrm{pH}$ range, whereas the other conditions remained constant (ZIF- 67 dose of $0.4 \mathrm{~g} / \mathrm{L}$, contact time of $20 \mathrm{~min}$, and $298 \mathrm{~K}$ temperature). The $\mathrm{pH}$ of the PSMP solution was adjusted with $\mathrm{HCl}(1 \mathrm{~mol} / \mathrm{L})$ or $\mathrm{NaOH}(1 \mathrm{~mol} / \mathrm{L})$. The effect of temperature on the PSMP $(5 \mathrm{mg} / \mathrm{L})$ adsorption by ZIF-67 $(0.4 \mathrm{~g} / \mathrm{L})$ from the water environment was analyzed by setting the temperature at 288,298 , and $308 \mathrm{~K}$, with a contact time of $20 \mathrm{~min}$.

The PSMP adsorption rate $(\eta)$ and capacity $\left(q_{t}\right)$ of ZIF-67 were calculated using Equations (1) and (2), respectively:

$$
\begin{aligned}
& \eta=\frac{C_{0}-C_{t}}{C_{0}} \times 100 \% \\
& q_{t}=\left(C_{0}-C_{t}\right) \times \frac{v}{m}
\end{aligned}
$$

where $C_{0}(\mathrm{mg} / \mathrm{L})$ is the initial concentration of PSMPs; $C_{t}(\mathrm{mg} / \mathrm{L})$ is the concentration of PSMPs in the solution after time $t(\mathrm{~min}) ; v(\mathrm{~L})$ is the volume of the PSMP solution; $m(\mathrm{~g})$ is the ZIF-67 dose in the solution.

\subsection{Adsorption Model}

The kinetics and isotherm models for PSMPs adsorbed by ZIF-67 were studied to explore the adsorption behavior of PSMPs particles by ZIF-67. Here, the pseudo-firstorder model (Equation (3)) and pseudo-second-order model (Equation (4)) were used to fit the kinetic experimental results for PSMPs adsorbed by ZIF-67. Furthermore, the adsorption isotherms were fitted by the Langmuir model (Equation (5)) and Freundlich model (Equation (6)).

$$
q_{t}=q_{e}\left(1-e^{-k_{1} t}\right)
$$




$$
\begin{gathered}
q_{t}=\frac{q_{e}^{2} k_{2} t}{1+q_{e} k_{2} t} \\
\frac{C_{e}}{q_{e}}=\frac{1}{k_{l} q_{m}}+\frac{1}{q_{m}} \\
\ln q_{e}=\ln k_{F}+\frac{1}{n} \ln C_{e}
\end{gathered}
$$

where $q_{e}(\mathrm{mg} / \mathrm{g})$ and $q_{m}$ represent the equilibrium and maximum theoretical adsorption capacity of PSMPs by ZIF-67, respectively; $k_{1}\left(\mathrm{~min}^{-1}\right)$ and $k_{2} \mathrm{mg} /(\mathrm{g} \times \mathrm{min})$ are the equation constants for the pseudo-first-order model and pseudo-second-order model, respectively. $K_{l}(\mathrm{~L} / \mathrm{mg})$ and $k_{f}$ are constants for the Langmuir model and Freundlich model, respectively; $n$ is the Freundlich model constant; $q_{m}(\mathrm{mg} / \mathrm{g})$ is the maximum theoretical adsorption capacity.

\section{Results and Discussion}

\subsection{Material Characterization}

The SEM and fluorescence images of the PSMPs, ZIF-67, and the ZIF-67/PSMP composite after adsorption are illustrated in Figure 1. As shown in the figure, the original PSMPs exhibited a smooth surface and uniform spherical shape, with particle sizes ranging from 1.0 to $3.0 \mu \mathrm{m}$. As demonstrated by both the SEM and fluorescence images, the ZIF-67 particles were irregular, with diameters ranging from 30 to $600 \mathrm{~nm}$ and a relatively smooth surface. However, compared with the PSMPs, the fluorescence of ZIF-67 was markedly weaker and was almost negligible. After adsorption, the fluorescence of the ZIF-67/PSMP composite in the aqueous solution was markedly increased, indicating that the PSMPs had attached to the surface of ZIF-67. These findings further confirmed that the PSMPs particles were effectively adsorbed by ZIF-67 in the aqueous solution.
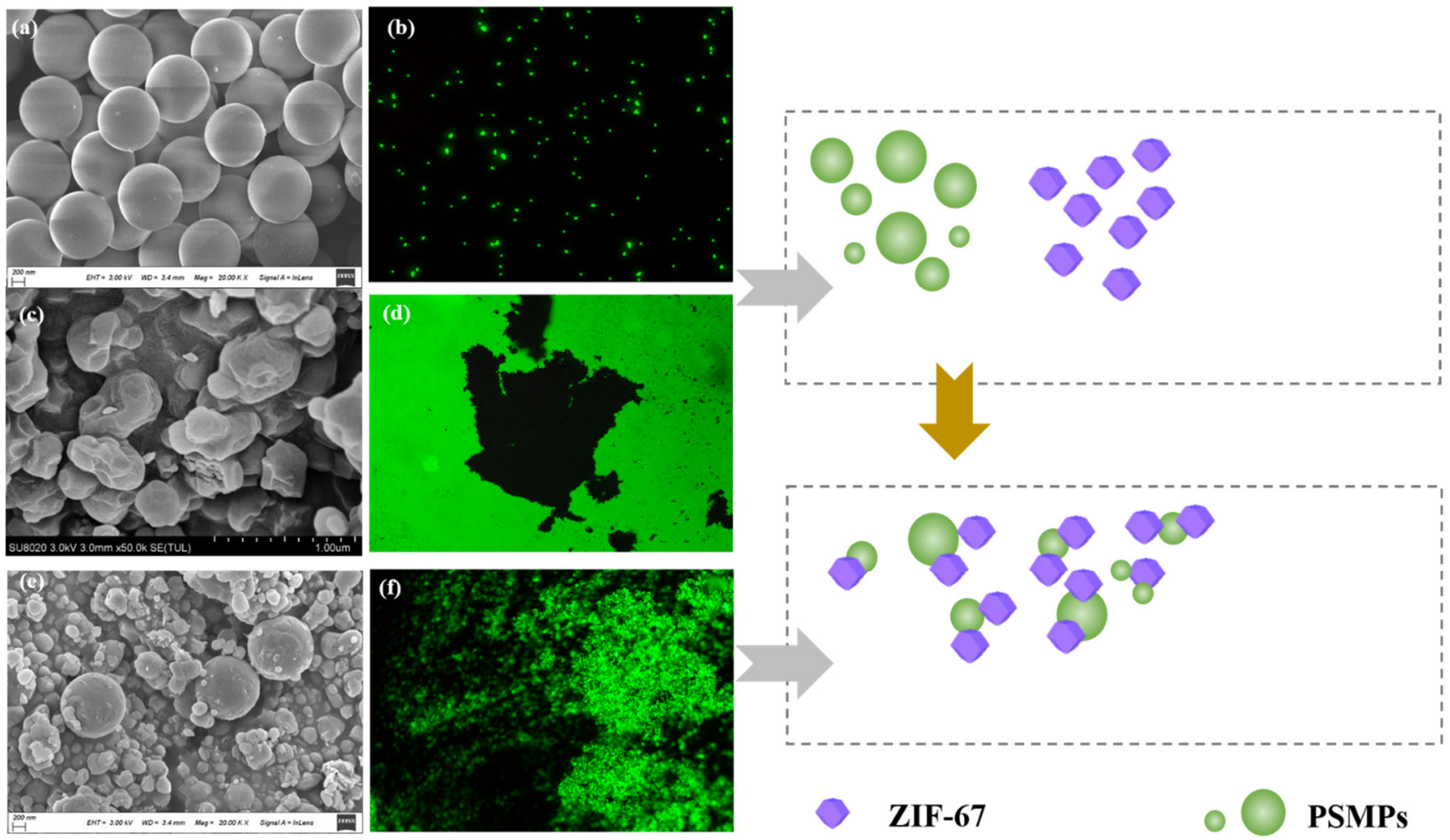

Figure 1. SEM and fluorescence image of PSMPs (a,b), ZIF-67 (c,d), and the ZIF-67/PSMP composite after adsorption $(\mathbf{e}, \mathbf{f})$, and schematic representation of PSMP adsorption by ZIF-67.

Figure 2a illustrates the hydrodynamic diameter distribution for the single ZIF-67 and PSMPs. As shown in the figure, the average diameters of ZIF-67 and PSMPs were 
approximately $92 \mathrm{~nm}$ and $1.45 \mu \mathrm{m}$, respectively. The Zeta potential (Figure 2b) of ZIF-67 and PSMPs were significantly different at a $\mathrm{pH}$ range of 3-12. The Zeta potential of the PSMPs was almost negative at the aforementioned $\mathrm{pH}$ range due to the presence of sulfate in the PSMPs $[48,49]$. Sulfate groups are negatively charged at a 2-12 pH range [48-50]. However, at a 6-10 $\mathrm{pH}$ range, the Zeta potential of ZIF-67 increased, and ZIF-67 became positively charged. Once the $\mathrm{pH}$ exceeded 10, ZIF-67 tended to be negatively charged, which was attributed to the $\mathrm{OH}^{-}$derived from water and hydrolysis of uncoordinated $\mathrm{Co}^{2+}$ on the surface of ZIF-67 [47,51]. These variations in the Zeta potential of ZIF-67 and PSMPs in aqueous solution might determine the PSMP removal performance of ZIF-67.

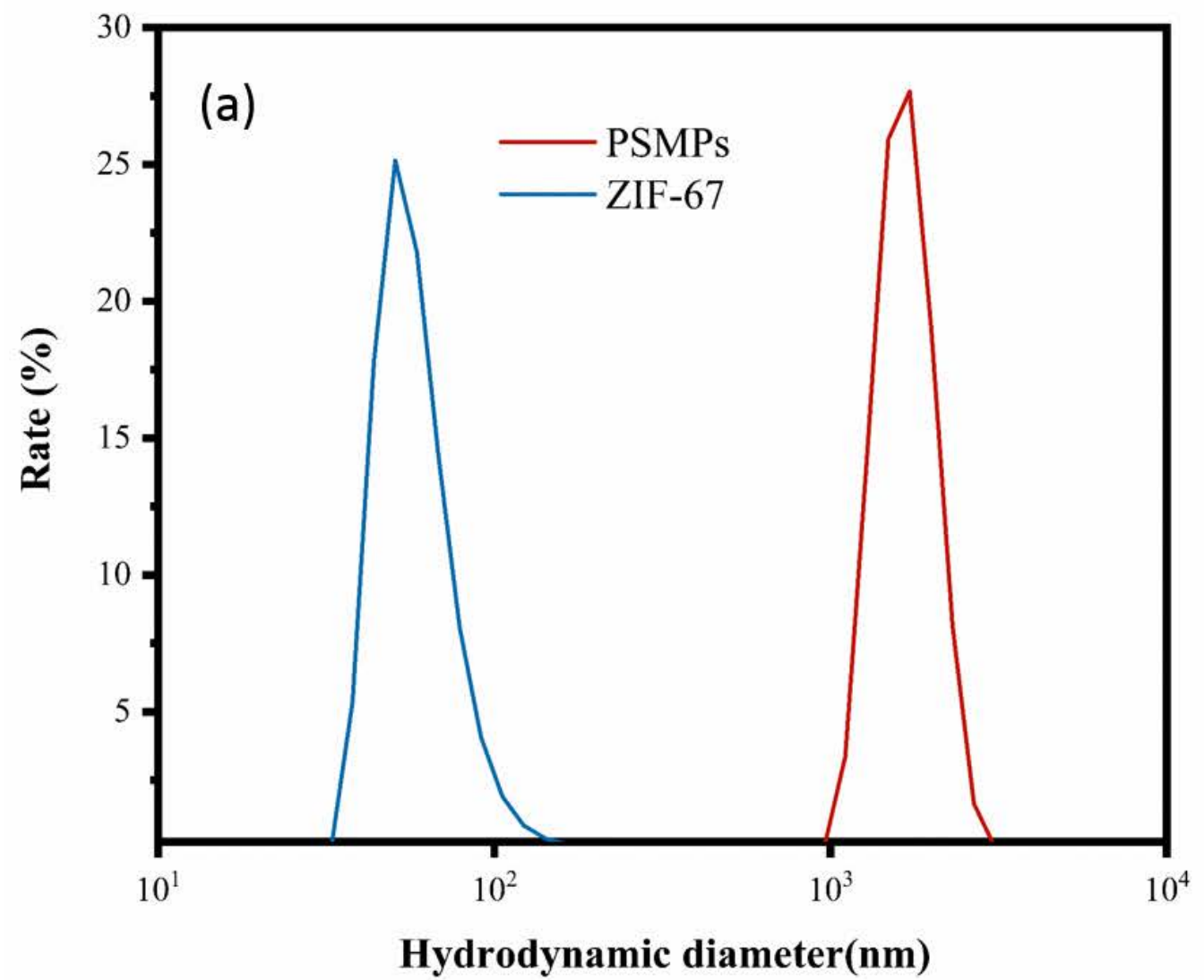

Figure 2. Hydrodynamic diameter distribution (a) and Zeta potential (b) of PSMPs and ZIF-67 in aqueous solution.

The FTIR spectra for PSMPs and ZIF-67 during the adsorption process are illustrated in Figure 3. For PSMPs, the absorption peak at $700 \mathrm{~cm}^{-1}$ was attributed to the single substitution peak of the benzene ring [52]. The peaks for PSMPs at 1450, 1500, and $1600 \mathrm{~cm}^{-1}$ were attributed to the skeleton vibration of the benzene ring $[53,54]$. Moreover, the peaks at 2850,2925 , and $3031 \mathrm{~cm}^{-1}$ in the PSMPs were mainly attributed to the C-H stretching of aliphatic compounds, whereas the peak at $3420 \mathrm{~cm}^{-1}$ was assigned to $-\mathrm{OH}$ in the PSMPs $[55,56]$. The FTIR peak for ZIF-67 was mainly ascribed to the ligand 2-methyl in the MOF material [57]. The peak observed at $600-1500 \mathrm{~cm}^{-1}$ was attributed to the stretching vibration of the imidazole ring in ZIF-67, whereas the peak at $3428 \mathrm{~cm}^{-1}$ was linked to the stretching vibration of $\mathrm{N}-\mathrm{H}$ and $-\mathrm{OH}$ [43]. After the adsorption process, the characteristic peaks for PSMPs $\left(700,1450,1500,1600,2850,2925,3031\right.$, and $\left.3420 \mathrm{~cm}^{-1}\right)$ were observed in the ZIF-67/PSMP composite, thus confirming that the PSMPs were adsorbed on the surface of ZIF-67. Additionally, the peak at $3300-3700 \mathrm{~cm}^{-1}$ in the ZIF-67 (after PSMP adsorption) was mainly related to the vibration of hydroxyl groups [51]. In turn, this hydroxyl vibration was mainly ascribed to the interaction between Co-OH or -NH (in ZIF-67) and the -OH (in PSMPs) $[43,47,58]$. Furthermore, the imidazole ring (in ZIF-67) could be regarded as 
an aromatic compound, which could interact with other aromatic compounds (in PSMPs) through $\pi-\pi$ stacking interaction [43]. Therefore, the $\pi-\pi$ stacking interactions should also be presented between the ZIF-67 and in PSMPs in an aqueous solution [59,60]. Therefore, hydrogen bonding and $\pi-\pi$ stacking strengthened the interaction between ZIF- 67 and PSMPs in the aqueous solution.

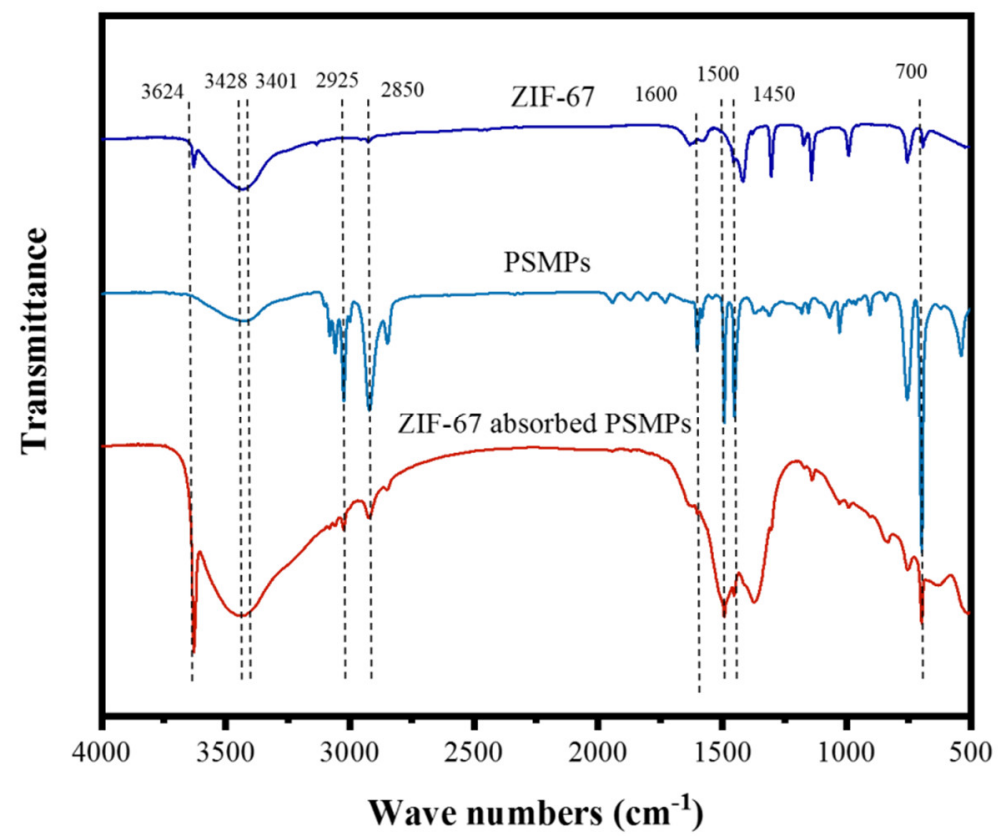

Figure 3. FTIR spectra for PSMPs and ZIF-67 during the adsorption process.

\subsection{Effect of ZIF-67 Dose}

Figure 4 illustrates the effect of the ZIF-67 dose on PSMP removal in aqueous solution. At a ZIF-67 dose ranging from 0.1 to $0.6 \mathrm{~g} / \mathrm{L}$, the adsorption ratio of PSMPs by ZIF-67 increased from $65.4 \%$ to $90.2 \%$. It could be attributed to the fact that more ZIF-67 could provide more adsorption sites for PSMPs. However, once the ZIF-67 dose exceeded $0.4 \mathrm{~g} / \mathrm{L}$, the adsorption ratio remained largely constant. Furthermore, the adsorption capacity of PSMPs by ZIF-67 decreased from 34.5 to $7.2 \mathrm{mg} / \mathrm{g}$ when the ZIF-67 dose increased from 0.1 to $0.6 \mathrm{~g} / \mathrm{L}$ (Equation (2)). The highest adsorption rate (92.1\%) and adsorption capacity $(11.6 \mathrm{mg} / \mathrm{g})$ of PSMPs in an aqueous solution was observed at a ZIF-67 dosage of $0.4 \mathrm{~g} / \mathrm{L}$. Thus, the optimal dosage of ZIF-67 for the removal of PSMPs should be selected as $0.4 \mathrm{~g} / \mathrm{L}$.

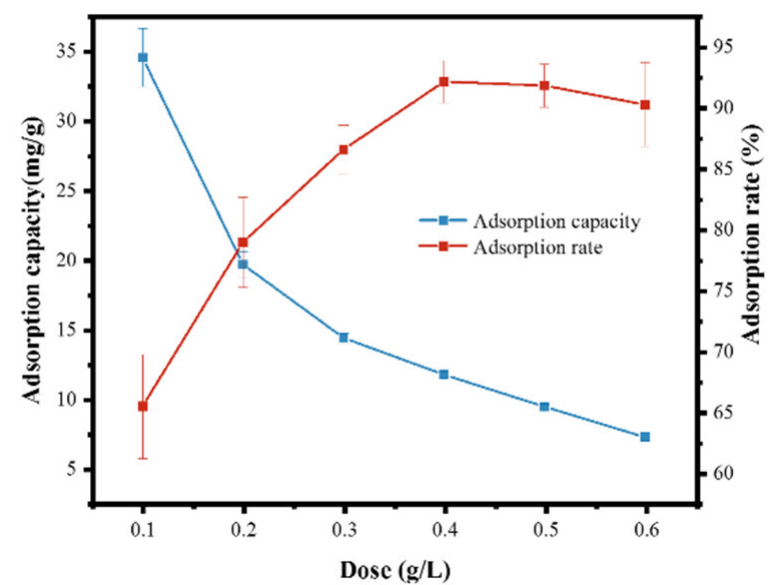

Figure 4. Effect of ZIF-67 dose on adsorption ratio and capacity of PSMPs in an aqueous solution. Conditions: PSMP concentration, $5 \mathrm{mg} \mathrm{L}^{-1}$; temperature, $298 \mathrm{~K}$; reaction time, $20 \mathrm{~min}$. 


\subsection{Adsorption Kinetics Model of PSMPs by ZIF-67}

Figure 5 illustrates the adsorption capacity of PSMPs by ZIF-67 with increasing contact time. In the first $20 \mathrm{~min}$, the PSMPs would be rapidly adsorbed by ZIF-67, reaching a maximum adsorption capacity of $11.6 \mathrm{mg} / \mathrm{g}$. Once the contact time exceeded $20 \mathrm{~min}$, the PSMP adsorption capacity of ZIF-67 remained largely constant. Our findings thus indicated that the adsorption of PSMPs by ZIF-67 in aqueous solution is a relatively fast process.

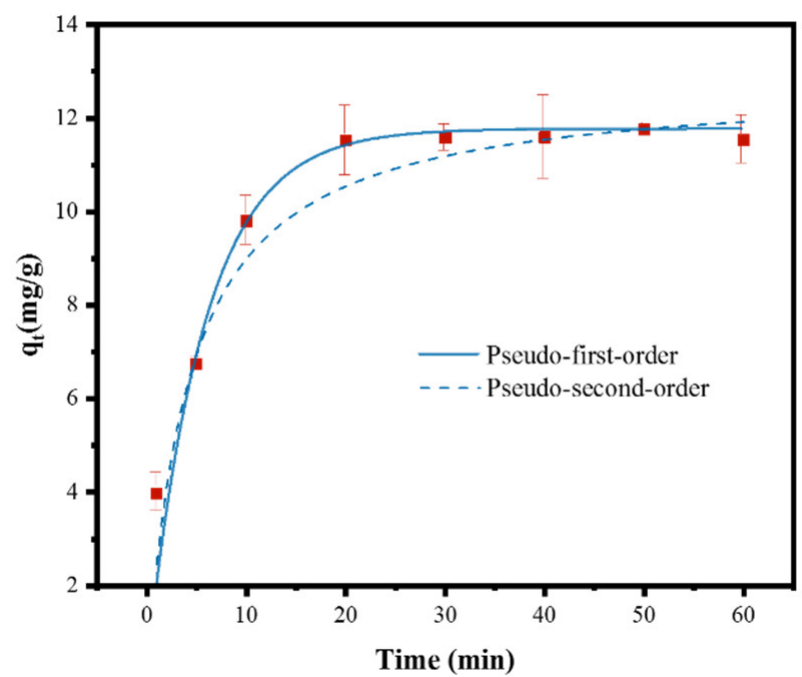

Figure 5. Fitting kinetic model for PSMP adsorption by ZIF-67. Conditions: PSMP concentration, $5 \mathrm{mg} \mathrm{L}^{-1}$; ZIF-67 dose, $0.4 \mathrm{~g} / \mathrm{L}$; temperature, $298 \mathrm{~K}$, reaction time, $20 \mathrm{~min}$.

The experimental results for the adsorption of PSMP by ZIF-67 were fitted by the pseudo-first-order and pseudo-second-order models, as shown in Figure 5 and Table 1. The calculated $\mathrm{R}^{2}$ for the pseudo-second-order kinetic model (0.981) was close to that of the pseudo-first-order model (0.977). However, the theoretical equilibrium adsorption capacity $(11.7 \mathrm{mg} / \mathrm{g})$ calculated by the pseudo-first-order kinetic equation was closer to the actual adsorption capacity $(11.6 \mathrm{mg} / \mathrm{g})$. Therefore, the pseudo-first-order kinetic equation was deemed more suitable for describing the adsorption of PSMPs by ZIF-67. These findings indicate that the removal of PSMPs by ZIF-67 is largely mediated by physical adsorption [61]. The adsorption rate constant of ZIF-67 for PSMPs was $0.171 \mathrm{~min}^{-1}$, which meant that ZIF-67 could reach the adsorption equilibrium for PSMPs within a short time [62].

Table 1. Kinetic model and parameters of adsorption of PSMPs by ZIF-67.

\begin{tabular}{ccccccc}
\hline \multirow{2}{*}{ Adsorbent } & \multicolumn{3}{c}{ Pseudo-First-Order } & \multicolumn{3}{c}{ Pseudo-Second-Order } \\
\cline { 2 - 7 } & $\mathbf{q}_{\boldsymbol{e}}$ & $\mathbf{K}_{1}$ & $\mathbf{R}^{\mathbf{2}}$ & $\mathbf{q}_{\boldsymbol{e}}$ & $\mathbf{K}_{2}$ & $\mathbf{R}^{\mathbf{2}}$ \\
\hline ZIF-67 & 11.7 & 0.171 & 0.977 & 12.7 & 0.018 & 0.981 \\
\hline
\end{tabular}

\subsection{Effect of $p H$}

Figure 6 illustrates the effect of $\mathrm{pH}$ on the adsorption of PSMPs by ZIF-67 in an aqueous solution. The schematic of the adsorption of PSMPs by ZIF- 67 with the influence of increasing $\mathrm{pH}$ was shown in Figure 7. As shown in the figure, the adsorption rate of PSMPs by ZIF-67 was maintained at approximately $88.3 \%$ at a $3-10 \mathrm{pH}$ range. This high PSMPs adsorption rate at the aforementioned $\mathrm{pH}$ range was mainly attributed to the stronger electrostatic attraction between the positively charged ZIF-67 and the negatively charged PSMPs. Moreover, the $\pi-\pi$ stacking and hydrogen bonding between the ZIF-67 and PSMPs also likely improved the removal of PSMPs in aqueous solution. When $\mathrm{pH}$ increased further to an 11-12 range, the repulsion force between the negatively charged ZIF-67 and negatively charged PSMPs at strongly alkaline conditions reduced the removal 
ratio of PSMPs by ZIF-67 from 88.3\% to 64.4\%. Therefore, ZIF-67 could effectively adsorb PSMPs with a $\mathrm{pH}$ ranging from 3 to 10, while the highest PSMPs adsorption rate was observed at a $\mathrm{pH}$ around 8 .

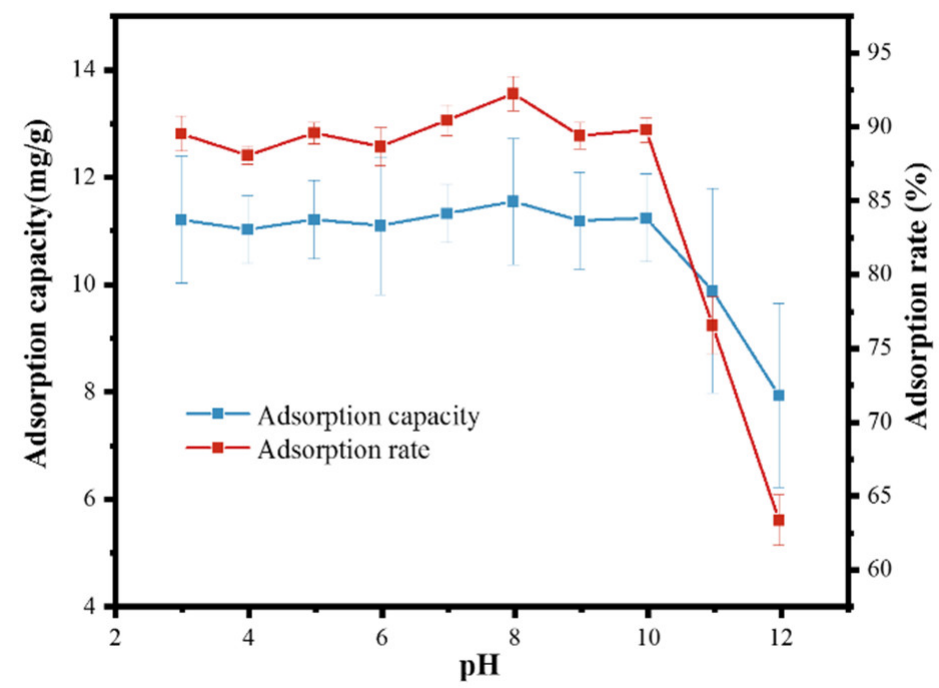

Figure 6. Effect of $\mathrm{pH}$ on PSMP adsorption capacity and rate by ZIF-67 (conditions: PSMP concentration, $5 \mathrm{mg} \mathrm{L}^{-1}$; ZIF-67 dose, $0.4 \mathrm{~g} / \mathrm{L}$; temperature, $298 \mathrm{~K}$; reaction time, $20 \mathrm{~min}$ ).

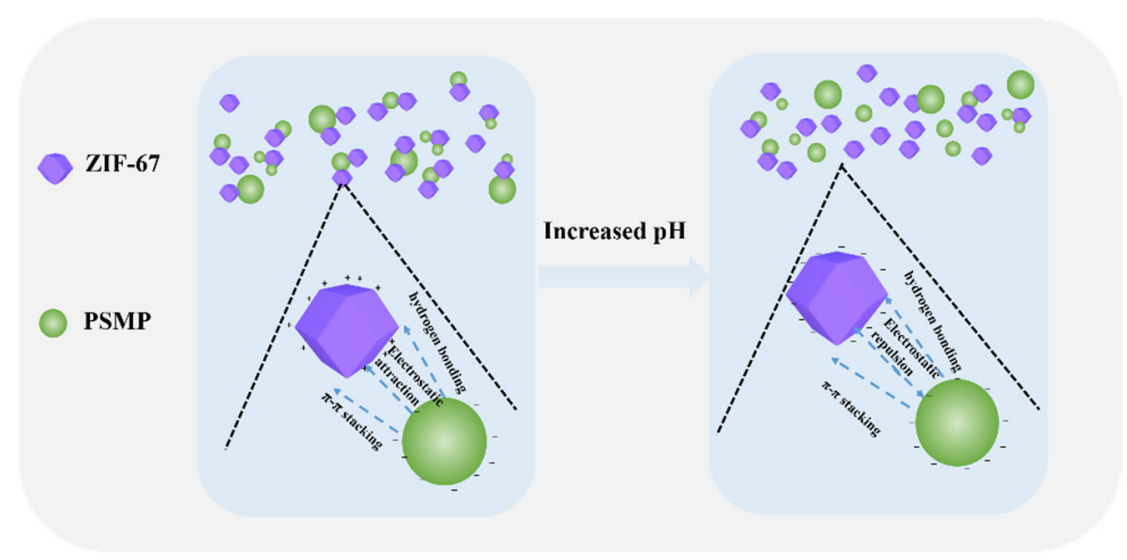

Figure 7. The schematic of the adsorption of PSMPs by ZIF-67 with the influence of increasing $\mathrm{pH}$.

\subsection{Adsorption Isotherm Analysis}

The adsorption isotherm for the adsorption of PSMPs by ZIF-67 in an aqueous solution was also investigated (Figure 8); the fitting parameters are summarized in Table 2 . The fitting coefficient $\left(\mathrm{R}^{2}\right)$ for the Freundlich model $(0.997)$ was much greater than that of the Langmuir model (0.474), indicating that the Freundlich model was more suitable to describe the adsorption of PSMPs by ZIF-67 in the aqueous solution. Additionally, this confirmed that the adsorption process is controlled by a multilayer adsorption mechanism. The fitting model results also indicated that the surface adsorption energy of ZIF-67 was uneven and that the adsorption of PSMPs by ZIF-67 could be attributed to hydrophobicity $[36,63,64]$. In the Freundlich model, the $k_{f}$ value and the $1 / \mathrm{n}$ value indicated the favorability of ZIF-67, to interact with PSMPs [65]. Thus, the value of $1 / \mathrm{n}(0.327)$ and $k_{f}(2.58)$ confirmed that ZIF-67 would readily interact with PSMPs [64,65]. The ZIF-67 would maintain a high adsorption rate (>82.2\%) with ranging PSMPs concentrations $(5 \mathrm{mg} / \mathrm{L}-50 \mathrm{mg} / \mathrm{L})$, indicating a superior state for removal of PSMPs by the ZIF-67. 

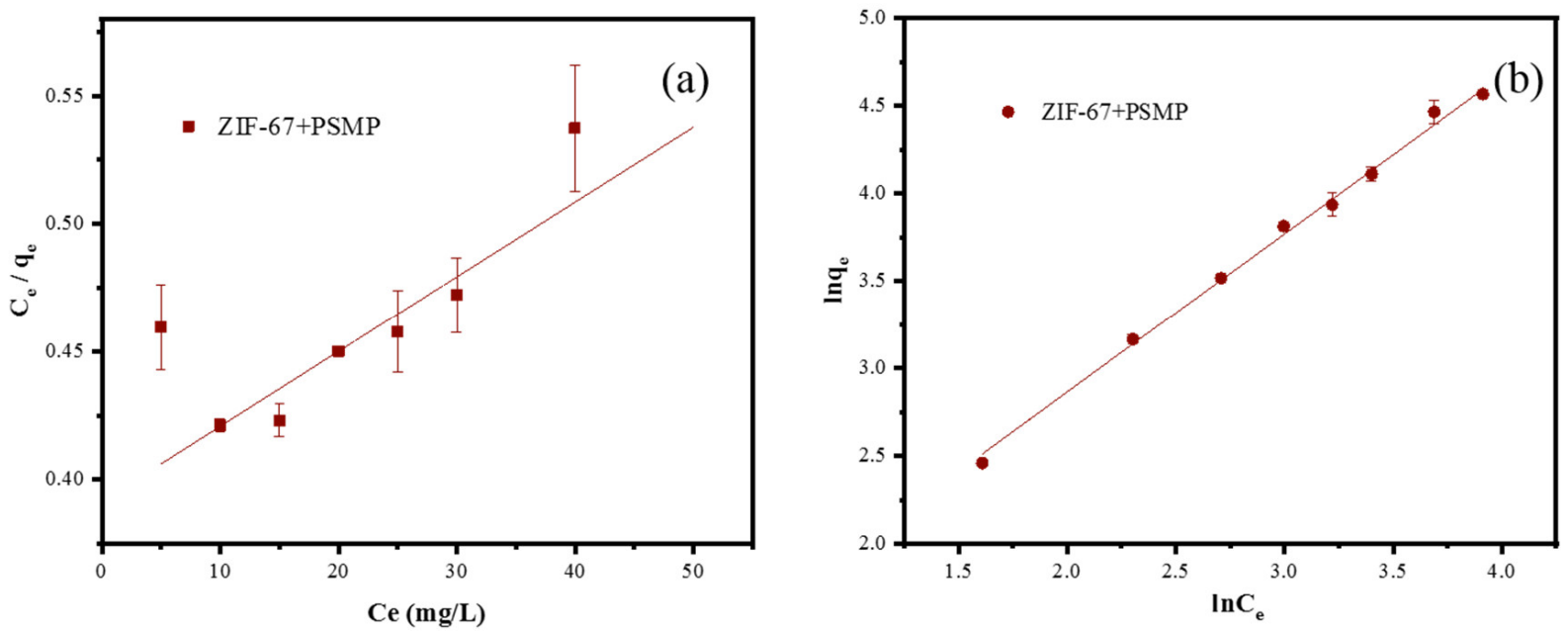

Figure 8. Fitting adsorption isotherm models of PSMPs by ZIF-67 (conditions: PSMPs concentration, $5 \mathrm{mg} \mathrm{L}{ }^{-1}$; ZIF-67 dose, $0.4 \mathrm{~g} / \mathrm{L}$; temperature, $298 \mathrm{~K}$; reaction time, $20 \mathrm{~min}$ ). (a) Langmuir model; (b) Freundlich model.

Table 2. Adsorption isotherm models and parameters of adsorption of PSMPs by ZIF- 67.

\begin{tabular}{ccccccc}
\hline \multirow{2}{*}{ Adsorbent } & \multicolumn{3}{c}{ Langmuir } & \multicolumn{3}{c}{ Freundlich } \\
\cline { 2 - 7 } & $\boldsymbol{K}_{1}$ & $\mathbf{q}_{\boldsymbol{m}}$ & $\mathbf{R}^{\mathbf{2}}$ & $\boldsymbol{K}_{f}$ & $1 / \mathbf{n}$ & $\mathbf{R}^{\mathbf{2}}$ \\
\hline ZIF-67 & 0.002 & 1369.8 & 0.474 & 2.58 & 0.346 & 0.997 \\
\hline
\end{tabular}

\subsection{Effect of Temperature}

Figure 9 illustrates the effect of contact temperature on the adsorption of PSMPs by ZIF-67. When the contact temperature ranged from 288 to $308 \mathrm{~K}$, the PSMP adsorption rate by ZIF-67 in the aqueous solution first increased slightly (from $83.1 \%$ to $92.1 \%$ ) and then decreased (from $92.1 \%$ to $86.4 \%$ ). This increase in adsorption capacity (from $10.3 \mathrm{mg} / \mathrm{g}$ to $11.5 \mathrm{mg} / \mathrm{g}$ ) with increasing contact temperature (from $288 \mathrm{~K}$ to $298 \mathrm{~K}$ ) was linked to the fact that the adsorption of PSMPs by ZIF-67 was mainly driven by physical adsorption (particularly at $288 \mathrm{~K}$ ). Here, the adsorption of PSMPs by ZIF-67 was mainly attributed to chemical adsorption, whereas the number of adsorption active sites at $298 \mathrm{~K}$ increased with increasing contact temperature. However, the slight decrease in adsorption capacity observed in our experiments (from 11.5 to $10.6 \mathrm{mg} / \mathrm{g}$ ) was likely due to the desorption of PSMPs from the ZIF-67 due to the increase in the thermal motion of particles with increasing temperature [66,67]. Therefore, our findings confirmed that increasing the temperature negatively affects the removal of MPs by MOF materials in aqueous solution. Furthermore, the relatively higher adsorption rate (92.1\%) of PSMPs by ZIF-67 was determined at a contact temperature of $298 \mathrm{~K}$. The correlation observed between adsorption rate and temperature was not obvious; thus, the Freundlich model constants at varying temperatures could not be calculated. Therefore, the thermodynamic results would not be further discussed.

\subsection{Compared with Other Treatments Technologies}

Different treatment technologies for removing microplastics are summarized in Table 3, including the adsorption, flocculation, electrocoagulation, and MBR route. For the flocculation method, the additional chemical reagents of PAC (200 mg/L) and PAM (100 mg/L) would be added, with MPs removal rate of $54.7 \%$ during the flocculation process [68]. Higher operating cost would be consumed in the MBR system, with PE/PET removal efficiency of $98.5 \%$ within $35 \mathrm{~h}$ [69]. The electrocoagulation route would remove more than $91 \%$ of microplastics with an applied voltage density of $10 \mathrm{~V}$ [70]. In addition, the electrocoagulation process would require $\mathrm{Na}_{2} \mathrm{SO}_{4}(0.05 \mathrm{M})$ to improve the conductivity of the solution $[70,71]$. The activated sludge process or biodegradation route had a relatively 
lower operating cost and wider application range; however, they took a longer time (more than 56 days) and the removal rate of microplastics still needed to be improved [72,73]. M-CNTs (5 g/L) could nearly remove all of PSMPs $(5 \mathrm{~g} / \mathrm{L})$ in an aqueous solution, and the reaction time was up to $5 \mathrm{~h}$. From the above comparison, the ZIF-67 materials have advantages including a short reaction time $(20 \mathrm{~min})$, relatively higher removal efficiency $(92.1 \%)$, and a simple operation process.

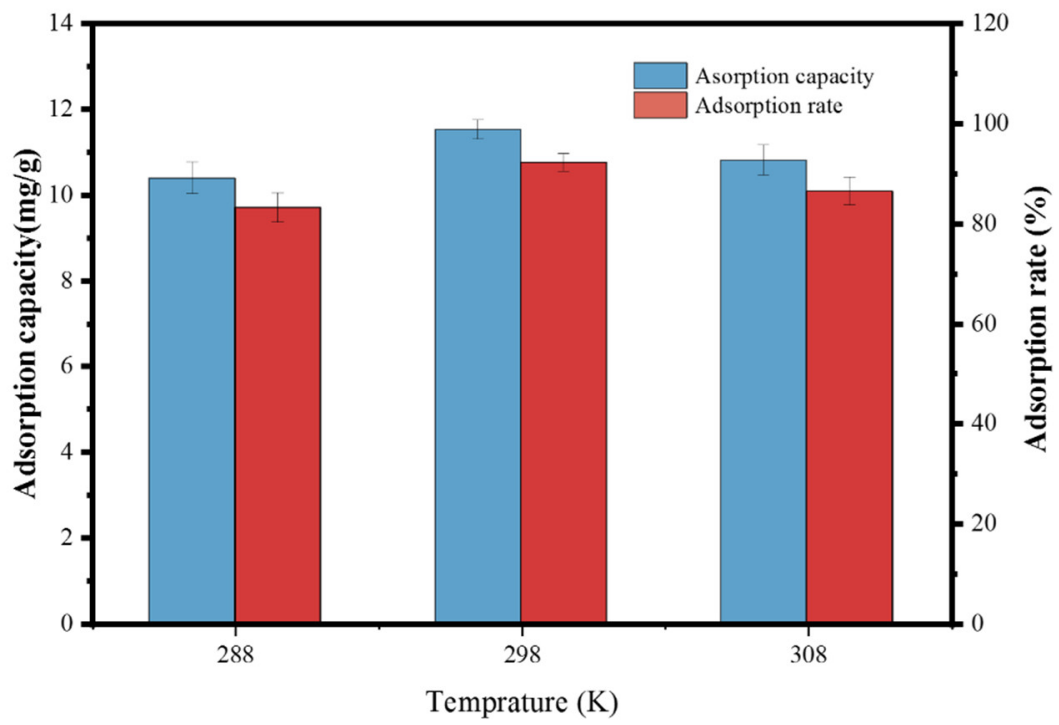

Figure 9. Effect of temperature on the PSMP adsorption performance of ZIF-67 (conditions: PSMP concentration, $5 \mathrm{mg} \mathrm{L}^{-1}$; ZIF-67 dose, $0.4 \mathrm{~g} / \mathrm{L}$; contact time, $20 \mathrm{~min}$ ).

Table 3. Methods for the removal of microplastics.

\begin{tabular}{|c|c|c|c|c|c|c|}
\hline Order & Type of Microplastics & Method & MP Size & Removal Efficiency & Experimental Details & Reference \\
\hline 1 & PS & $\begin{array}{c}\text { Adsorption by } \\
\text { ZIF-67 }\end{array}$ & $1.45 \mu \mathrm{m}$ & $92.1 \%$ & $\begin{array}{l}\text { MPs }(5 \mathrm{mg} / \mathrm{L}), \mathrm{ZIF}-67(0.4 \mathrm{~g} / \mathrm{L}) \\
\text { contact temperature }(298 \mathrm{~K}) \\
\text { contact time }(20 \mathrm{~min})\end{array}$ & This work \\
\hline 2 & PE, PET, PA & $\begin{array}{c}\text { Adsorption by } \\
\text { M-CNTs }\end{array}$ & $48 \mu \mathrm{m}$ & $100 \%$ & $\begin{array}{c}\text { MPs }(5 \mathrm{~g} / \mathrm{L}), \mathrm{M}-\mathrm{CNTs}(5 \mathrm{~g} / \mathrm{L}) \\
\text { contact temperature }(298 \mathrm{~K}), \\
\text { contact time }(5 \mathrm{~h})\end{array}$ & [74] \\
\hline 3 & PET & Coagulation & $100-400 \mu \mathrm{m}$ & $54.7 \%$ & $\begin{array}{c}\text { PAC (100 mg/L), PAM } \\
\text { (200 mg/L), MPs }(100 \mathrm{mg}), \\
\text { stirring speed of } 500 \mathrm{rpm} \text { for } 1 \\
\text { min and followed by } 100 \mathrm{rpm} \\
\text { for } 15 \mathrm{~min}\end{array}$ & [68] \\
\hline 4 & PA, PP, PE, PVC & Activated sludge & $0.02-0.3 \mathrm{~mm}$ & $64.4 \%$ & $\begin{array}{c}\text { The abundance of MPs in the } \\
\text { influent }(79.9 \mathrm{n} / \mathrm{L})\end{array}$ & [72] \\
\hline 5 & PS & Biodegradation & $0.3-1.25 \mathrm{~mm}$ & $43.7 \%$ & $\begin{array}{l}\text { Basal medium (liquid } \\
\text { carbon-free basal medium), } \\
\text { temperature }\left(40^{\circ} \mathrm{C} \text { or } 70{ }^{\circ} \mathrm{C}\right), \\
\text { contact time }(56 \text { days) }\end{array}$ & [73] \\
\hline 6 & PMMA, PE, CA, PP & Electrocoagulation & $\begin{array}{l}\text { PE: } 286.7 \mu \mathrm{m}, \\
\text { PMMA: } 6.3 \mu \mathrm{m}, \\
\text { PP: } 1-2 \mathrm{~mm}, \\
\text { CA: } 1-2 \mathrm{~mm}\end{array}$ & $\begin{array}{l}\text { 93.2\% for } \mathrm{PE}, \\
91.7 \% \text { for PMMA, } \\
98.2 \% \text { for } \mathrm{CA} \text {, and } \\
\text { 98.4\% for } \mathrm{PP}\end{array}$ & $\begin{array}{c}\text { Electrolyte }\left(0.05 \mathrm{M} \mathrm{Na}_{2} \mathrm{SO}_{4}\right), \mathrm{pH} \\
(7.2) \text {, applied voltage density } \\
(10 \mathrm{~V}) \text {, anode }(\mathrm{Al})\end{array}$ & [70] \\
\hline 7 & PE, PET & MBR & $<5 \mathrm{~mm}$ & $98.5 \%$ & $\begin{array}{c}\text { MBR pilot plant, Suction } \\
\text { cycle(9 min-ON/1 min-OFF), } \\
\operatorname{HRT}(35 \mathrm{~h})\end{array}$ & [69] \\
\hline
\end{tabular}

\section{Conclusions}

This paper mainly focused on the mechanism for interface between microplastics and the prepared MOF materials. The current experiment mainly studied the influence mechanism of single key factors on the adsorption of microplastics. Our research showed that the ZIF-67 could effectively absorb different concentrations of PSMPs (5-50 mg/L) in a 
wide $\mathrm{pH}$ range (3-10), and a temperature ranging from 288 to $308 \mathrm{~K}$. In addition, compared with other technologies for removing PSMPs from water, ZIF-67 showed the superiority including a lower cost and higher treatment efficiency.

This process was a challenging attempt, which not only provided a novel technology for effectively removing microplastics in acidic and weakly alkaline wastewater, but also expanded the application of porous materials in removing pollutants in aqueous solutions. Further tests would be recommendable to verify the reusability of MOF materials in the adsorption process. We would also add more experimental groups to the further investigation.

Author Contributions: Methodology and writing—original draft preparation, H.W. and J.W.; methodology X.S. and J.Y.; writing—review and editing, W.Z.; writing—review and editing, Y.X. All authors have read and agreed to the published version of the manuscript.

Funding: This research was funded by the Natural Sciences Foundation of China (Grant No. 52000163), the Natural Sciences Foundation of China (Grant No. 51779230), the Key Project of Natural Science Foundation of China-Xinjiang Joint Fund (Grant No. U1803241), the Natural Science Foundation of Henan Province (Grant No. 202300410423), the Open Research Fund of Henan Key Laboratory of Water Resources Conservation and Intensive Utilization in the Yellow River Basin (Grant NO. 2021-01), and the Open fund from Henan Key Laboratory of Water Pollution Control and Rehabilitation Technology (CJSZ2021001).

Institutional Review Board Statement: Not applicable.

Informed Consent Statement: Not applicable.

Data Availability Statement: Not applicable.

Acknowledgments: The authors would like to thank the Modern Analysis and Gene Sequencing Center of Zhengzhou University and Proryan Test Co., Ltd. for their important contributions to this study.

Conflicts of Interest: The authors declare no conflict of interest.

$\begin{array}{ll}\text { Abbreviations } \\ \text { PS } & \text { Polystyrene } \\ \text { MPs } & \text { Microplastics } \\ \text { PSMPs } & \text { Polystyrene microplastics with micron size } \\ \text { MOF } & \text { Metal-organic framework } \\ \text { ZIF } & \text { Zeolitic imidazolate framework } \\ \text { XRD } & \text { X-ray diffraction } \\ \text { FTIR } & \text { Fourier transform infrared } \\ \text { SEM } & \text { Scanning electron microscope } \\ \text { PE } & \text { Polyethylene } \\ \text { PET } & \text { Polyethylene terephthalate } \\ \text { PA } & \text { Polyamide } \\ \text { M-CNTs } & \text { Magnetic carbon nanotubes } \\ \text { PAM } & \text { Polyacrylamide } \\ \text { PAC } & \text { Poly-aluminum chloride } \\ \text { PP } & \text { Polypropylene } \\ \text { PVC } & \text { Polyvinyl chloride } \\ \text { PMMA } & \text { Polymethylmethacrylate } \\ \text { CA } & \text { Cellulose acetate } \\ \text { MBR } & \text { Membrane bioreactor } \\ \text { HRT } & \text { Hydraulic retention time }\end{array}$




\section{References}

1. Rochman, C.M.; Hoh, E.; Kurobe, T.; Teh, S.J. Ingested plastic transfers hazardous chemicals to fish and induces hepatic stress. Sci. Rep. 2013, 3, 3263. [CrossRef] [PubMed]

2. Koelmans, A.A.; Bakir, A.; Burton, G.A.; Janssen, C.R. Microplastic as a vector for chemicals in the aquatic environment: Critical review and model-supported reinterpretation of empirical studies. Environ. Sci. Technol. 2016, 50, 3315-3326. [CrossRef] [PubMed]

3. Rios Mendoza, L.M.; Karapanagioti, H.; Álvarez, N.R. Micro(nanoplastics) in the marine environment: Current knowledge and gaps. Curr. Opin. Environ. Sci. Health 2018, 1, 47-51. [CrossRef]

4. Frias, J.P.G.L.; Nash, R. Microplastics: Finding a consensus on the definition. Mar. Pollut. Bull. 2019, 138, 145-147. [CrossRef] [PubMed]

5. Sheng, X.; Wang, J.; Zhang, W.; Zuo, Q. The Potential for PE microplastics to affect the removal of carbamazepine medical pollutants from aqueous environments by multiwalled carbon nanotubes. Toxics 2021, 9, 139. [CrossRef] [PubMed]

6. Cole, M.; Lindeque, P.; Halsband, C.; Galloway, T.S. Microplastics as contaminants in the marine environment: A review. Mar. Pollut. Bull. 2011, 62, 2588-2597. [CrossRef]

7. Alimi, O.S.; Farner Budarz, J.; Hernandez, L.M.; Tufenkji, N. Microplastics and nanoplastics in aaquatic environments: Aggregation, deposition, and enhanced contaminant transport. Environ. Sci. Technol. 2018, 52, 1704-1724. [CrossRef]

8. Zhang, Q.; Xu, E.G.; Li, J.; Chen, Q.; Ma, L.; Zeng, E.Y.; Shi, H. A review of microplastics in table salt, drinking water, and air: Direct human exposure. Environ. Sci. Technol. 2020, 54, 3740-3751. [CrossRef]

9. Su, Y.; Hu, X.; Tang, H.; Lu, K.; Li, H.; Liu, S.; Xing, B.; Ji, R. Steam disinfection releases micro(nano)plastics from silicone-rubber baby teats as examined by optical photothermal infrared microspectroscopy. Nat. Nanotechnol. 2021, 17, 76-85. [CrossRef]

10. Amelia, T.S.M.; Khalik, W.M.A.W.M.; Ong, M.C.; Shao, Y.T.; Pan, H.-J.; Bhubalan, K. Marine microplastics as vectors of major ocean pollutants and its hazards to the marine ecosystem and humans. Prog. Earth Planet. Sci. 2021, 8, 12. [CrossRef]

11. Ahmad, M.; Li, J.-L.; Wang, P.-D.; Hozzein, W.N.; Li, W.-J. Environmental perspectives of microplastic pollution in the aquatic environment: A review 6686. Mar. Life Sci. Technol. 2020, 2, 414-430. [CrossRef]

12. Velzeboer, I.; Kwadijk, C.J.A.F.; Koelmans, A.A. Strong sorption of PCBs to nanoplastics, microplastics, carbon nanotubes, and fullerenes. Environ. Sci. Technol. 2014, 48, 4869-4876. [CrossRef]

13. Liu, X.; Shi, H.; Xie, B.; Dionysiou, D.D.; Zhao, Y. Microplastics as both a sink and a source of bisphenol A in the marine environment. Environ. Sci. Technol. 2019, 53, 10188-10196. [CrossRef]

14. Palmer, J.; Herat, S. Ecotoxicity of microplastic pollutants to marine organisms: A systematic review. Water Air Soil Pollut. 2021, 232, 195. [CrossRef]

15. Ciobanu, C.-S.; Copae, R.; Bulgariu, D.; Bulgariu, L. Comparative study of Pb (II) ions adsorption on pet fibers and flakes: Isotherm, kinetic and mechanism considerations. Desalination Water Treat. 2021, 222, 375-385. [CrossRef]

16. Zhang, W.; Zhang, L.; Hua, T.; Li, Y.; Zhou, X.; Wang, W.; You, Z.; Wang, H.; Li, M. The mechanism for adsorption of Cr (VI) ions by PE microplastics in ternary system of natural water environment. Environ. Pollut. 2020, 257, 113440. [CrossRef] [PubMed]

17. Zhang, L.; Li, Y.; Wang, W.; Zhang, W.; Zuo, Q.; Abdelkader, A.; Xi, K.; Heynderickx, P.M.; Kim, K.-H. The potential of microplastics as adsorbents of sodium dodecyl benzene sulfonate and chromium in an aqueous environment. Environ. Res. 2021, 197, 111057. [CrossRef]

18. Redondo-Hasselerharm, P.E.; Falahudin, D.; Peeters, E.T.H.M.; Koelmans, A.A. Microplastic effect thresholds for freshwater benthic macroinvertebrates. Environ. Sci. Technol. 2018, 52, 2278-2286. [CrossRef]

19. Cole, M.; Lindeque, P.; Fileman, E.; Halsband, C.; Goodhead, R.; Moger, J.; Galloway, T.S. Microplastic Ingestion by Zooplankton. Environ. Sci. Technol. 2013, 47, 6646-6655. [CrossRef]

20. Cole, M.; Coppock, R.; Lindeque, P.K.; Altin, D.; Reed, S.; Pond, D.W.; Sørensen, L.; Galloway, T.S.; Booth, A.M. Effects of nylon microplastic on feeding, lipid accumulation, and molting in a Coldwater copepod. Environ. Sci. Technol. 2019, 53, 7075-7082. [CrossRef]

21. Wieczorek, A.M.; Croot, P.L.; Lombard, F.; Sheahan, J.N.; Doyle, T.K. Microplastic ingestion by gelatinous zooplankton may lower efficiency of the biological pump. Environ. Sci. Technol. 2019, 53, 5387-5395. [CrossRef] [PubMed]

22. Hermsen, E.; Mintenig, S.M.; Besseling, E.; Koelmans, A.A. Quality criteria for the analysis of microplastic in biota samples: A critical review. Environ. Sci. Technol. 2018, 52, 10230-10240. [CrossRef] [PubMed]

23. Nobre, C.R.; Santana, M.F.M.; Maluf, A.; Cortez, F.S.; Cesar, A.; Pereira, C.D.S.; Turra, A. Assessment of microplastic toxicity to embryonic development of the sea urchin Lytechinus variegatus (Echinodermata: Echinoidea). Mar. Pollut. Bull. 2015, 92, 99-104. [CrossRef]

24. Sharma, S.; Chatterjee, S. Microplastic pollution, a threat to marine ecosystem and human health: A short review. Environ. Sci. Pollut. Res. 2017, 24, 21530-21547. [CrossRef]

25. Cox, K.D.; Covernton, G.A.; Davies, H.L.; Dower, J.F.; Juanes, F.; Dudas, S.E. Human consumption of microplastics. Environ. Sci. Technol. 2019, 53, 7068-7074. [CrossRef]

26. Mohamed Nor, N.H.; Kooi, M.; Diepens, N.J.; Koelmans, A.A. Lifetime accumulation of microplastic in Children and adults. Environ. Sci. Technol. 2021, 55, 5084-5096. [CrossRef]

27. Mason, S.A.; Garneau, D.; Sutton, R.; Chu, Y.; Ehmann, K.; Barnes, J.; Fink, P.; Papazissimos, D.; Rogers, D.L. Microplastic pollution is widely detected in US municipal wastewater treatment plant effluent. Environ. Pollut. 2016, 218, 1045-1054. [CrossRef] [PubMed] 
28. Yuan, F.; Zhao, H.; Sun, H.; Sun, Y.; Zhao, J.; Xia, T. Investigation of microplastics in sludge from five wastewater treatment plants in Nanjing, China. J. Environ. Manag. 2022, 301, 113793. [CrossRef] [PubMed]

29. Vuori, L.; Ollikainen, M. How to remove microplastics in wastewater? A cost-effectiveness analysis. Ecol. Econ. 2022, 192, 107246. [CrossRef]

30. Collivignarelli, M.C.; Carnevale Miino, M.; Caccamo, F.M.; Milanese, C. Microplastics in sewage sludge: A known but underrated pathway in wastewater treatmentplants. Sustainability 2021, 13, 12591. [CrossRef]

31. Liu, W.; Zhang, J.; Liu, H.; Guo, X.; Zhang, X.; Yao, X.; Cao, Z.; Zhang, T. A review of the removal of microplastics in global wastewater treatment plants: Characteristics and mechanisms. Environ. Int. 2021, 146, 106277. [CrossRef]

32. Shen, M.; Hu, T.; Huang, W.; Song, B.; Zeng, G.; Zhang, Y. Removal of microplastics from wastewater with aluminosilicate filter media and their surfactant-modified products: Performance, mechanism and utilization. Chem. Eng. J. 2021, 421, 129918. [CrossRef]

33. Zhang, Y.; Jiang, H.; Bian, K.; Wang, H.; Wang, C. A critical review of control and removal strategies for microplastics from aquatic environments. J. Environ. Chem. Eng. 2021, 9, 105463. [CrossRef]

34. Ramirez Arenas, L.; Ramseier Gentile, S.; Zimmermann, S.; Stoll, S. Nanoplastics adsorption and removal efficiency by granular activated carbon used in drinking water treatment process. Sci. Total Environ. 2021, 791, 148175. [CrossRef] [PubMed]

35. Novotna, K.; Cermakova, L.; Pivokonska, L.; Cajthaml, T.; Pivokonsky, M. Microplastics in drinking water treatment-Current knowledge and research needs. Sci. Total Environ. 2019, 667, 730-740. [CrossRef]

36. Wang, J.; Sun, C.; Huang, Q.-X.; Chi, Y.; Yan, J.-H. Adsorption and thermal degradation of microplastics from aqueous solutions by $\mathrm{Mg} / \mathrm{Zn}$ modified magnetic biochars. J. Hazard. Mater. 2021, 419, 126486. [CrossRef] [PubMed]

37. Sun, C.; Wang, Z.; Chen, L.; Li, F. Fabrication of robust and compressive chitin and graphene oxide sponges for removal of microplastics with different functional groups. Chem. Eng. J. 2020, 393, 124796. [CrossRef]

38. Wan, H.; Yan, J.; Guo, C.; Cui, Q.; Zhang, W. Synthesis of core-heteroshell structure for ZIF-67/VTM and its efficient activation of peroxymonosulfate in treatment of levofloxacin from an aqueous solution. Environ. Res. 2022, 204, 111986. [CrossRef]

39. Li, Z.; Guo, Z.; Zhang, T.; Li, Q.; Chen, J.; Ji, W.; Liu, C.; Wei, Y. Fabrication of in situ ZIF-67 grown on alginate hydrogels and its application for enhancing Cu (II) adsorption from aqueous solutions. Colloids Surf. B Biointerfaces 2021, 207, 112036. [CrossRef]

40. Butova, V.V.; Polyakov, V.A.; Budnyk, A.P.; Aboraia, A.M.; Bulanova, E.A.; Guda, A.A.; Reshetnikova, E.A.; Podkovyrina, Y.S.; Lamberti, C.; Soldatov, A.V. Zn/Co ZIF family: MW synthesis, characterization and stability upon halogen sorption. Polyhedron 2018, 154, 457-464. [CrossRef]

41. Son, Y.-R.; Ryu, S.G.; Kim, H.S. Rapid adsorption and removal of sulfur mustard with zeolitic imidazolate frameworks ZIF-8 and ZIF-67. Microporous Mesoporous Mater. 2020, 293, 109819. [CrossRef]

42. Li, Y.; Zhou, K.; He, M.; Yao, J. Synthesis of ZIF-8 and ZIF-67 using mixed-base and their dye adsorption. Microporous Mesoporous Mater. 2016, 234, 287-292. [CrossRef]

43. Lin, K.-Y.A.; Chang, H.-A. Ultra-high adsorption capacity of zeolitic imidazole framework-67 (ZIF-67) for removal of malachite green from water. Chemosphere 2015, 139, 624-631. [CrossRef] [PubMed]

44. Qian, J.; Sun, F.; Qin, L. Hydrothermal synthesis of zeolitic imidazolate framework-67 (ZIF-67) nanocrystals. Mater. Lett. 2012, 82, 220-223. [CrossRef]

45. Huang, Y.; Zeng, X.; Guo, L.; Lan, J.; Zhang, L.; Cao, D. Heavy metal ion removal of wastewater by zeolite-imidazolate frameworks. Sep. Purif. Technol. 2018, 194, 462-469. [CrossRef]

46. Nguyen, D.T.C.; Vo, D.-V.N.; Nguyen, C.N.Q.; Pham, L.H.A.; Le, H.T.N.; Nguyen, T.T.T.; Tran, T.V. Box-Behnken design, kinetic, and isotherm models for oxytetracycline adsorption onto Co-based ZIF-67. Appl. Nanosci. 2021, 11, 2347-2359. [CrossRef]

47. Du, X.-D.; Wang, C.-C.; Liu, J.-G.; Zhao, X.-D.; Zhong, J.; Li, Y.-X.; Li, J.; Wang, P. Extensive and selective adsorption of ZIF-67 towards organic dyes: Performance and mechanism. J. Colloid Interface Sci. 2017, 506, 437-441. [CrossRef]

48. Li, Y.; Wang, X.; Fu, W.; Xia, X.; Liu, C.; Min, J.; Zhang, W.; Crittenden, J.C. Interactions between nano/micro plastics and suspended sediment in water: Implications on aggregation and settling. Water Res. 2019, 161, 486-495. [CrossRef]

49. Gallardo, V.; Ruiz, M.A.; López-Viota, M.; Morales, M.E.; López-Viota, J. Calorimetric, electrophoretic, and microscopic characterization of polymer-drug complexes. Adv. Polym. Technol. 2008, 27, 47-55. [CrossRef]

50. Lu, S.; Zhu, K.; Song, W.; Song, G.; Chen, D.; Hayat, T.; Alharbi, N.S.; Chen, C.; Sun, Y. Impact of water chemistry on surface charge and aggregation of polystyrene microspheres suspensions. Sci. Total Environ. 2018, 630, 951-959. [CrossRef]

51. Li, J.; Wu, Y.N.; Li, Z.; Zhang, B.; Zhu, M.; Hu, X.; Zhang, Y.; Li, F. Zeolitic imidazolate framework-8 with high efficiency in trace arsenate adsorption and removal from water. J. Phys. Chem. C 2014, 118, 27382-27387. [CrossRef]

52. Feng, X.; Yang, X.; Li, M.; Qin, J.; Li, Q.; Yu, X. Production and method optimization of fluorescent polystyrene. J. Mol. Struct. 2021, 1243, 130746. [CrossRef]

53. Xu, B.; Huang, D.; Liu, F.; Alfaro, D.; Lu, Z.; Tang, C.; Gan, J.; Xu, J. Contrasting effects of microplastics on sorption of diazepam and phenanthrene in soil. J. Hazard. Mater. 2021, 406, 124312. [CrossRef] [PubMed]

54. Ponnusamy, V.K.; Nagappan, S.; Bhosale, R.R.; Lay, C.-H.; Duc Nguyen, D.; Pugazhendhi, A.; Chang, S.W.; Kumar, G. Review on sustainable production of biochar through hydrothermal liquefaction: Physico-chemical properties and applications. Bioresour. Technol. 2020, 310, 123414. [CrossRef]

55. Li, Y.; Li, M.; Li, Z.; Yang, L.; Liu, X. Effects of particle size and solution chemistry on Triclosan sorption on polystyrene microplastic. Chemosphere 2019, 231, 308-314. [CrossRef] [PubMed] 
56. Harrison, J.P.; Ojeda, J.J.; Romero-González, M.E. The applicability of reflectance micro-Fourier-transform infrared spectroscopy for the detection of synthetic microplastics in marine sediments. Sci. Total Environ. 2012, 416, 455-463. [CrossRef] [PubMed]

57. Gross, A.F.; Sherman, E.; Vajo, J.J. Aqueous room temperature synthesis of cobalt and zinc sodalite zeolitic imidizolate frameworks. Dalton Trans. 2012, 41, 5458-5460. [CrossRef]

58. Chizallet, C.; Lazare, S.; Bazer-Bachi, D.; Bonnier, F.; Lecocq, V.; Soyer, E.; Quoineaud, A.-A.; Bats, N. Catalysis of Transesterification by a Nonfunctionalized Metal-Organic Framework: Acido-Basicity at the External Surface of ZIF-8 Probed by FTIR and ab Initio Calculations. J. Am. Chem. Soc. 2010, 132, 12365-12377. [CrossRef]

59. Zhang, Z.-H.; Zhang, J.-L.; Liu, J.-M.; Xiong, Z.-H.; Chen, X. Selective and competitive adsorption of azo dyes on the Metal-Organic Framework ZIF-67. Water Air Soil Pollut. 2016, 227, 471. [CrossRef]

60. Zhang, J.; Cai, Y.; Liu, K. Extremely effective boron removal from water by stable metal organic framework ZIF-67. Ind. Eng. Chem. Res. 2019, 58, 4199-4207. [CrossRef]

61. Gurav, R.; Bhatia, S.K.; Choi, T.-R.; Choi, Y.-K.; Kim, H.J.; Song, H.-S.; Park, S.L.; Lee, H.S.; Lee, S.M.; Choi, K.-Y.; et al. Adsorptive removal of crude petroleum oil from water using floating pinewood biochar decorated with coconut oil-derived fatty acids. Sci. Total Environ. 2021, 781, 146636. [CrossRef] [PubMed]

62. Liu, C.; Zhang, M.; Gao, H.; Kong, L.; Fan, S.; Wang, L.; Shao, H.; Long, M.; Guo, X. Cyclic coupling of photocatalysis and adsorption for completely safe removal of N-nitrosamines in water. Water Res. 2022, 209, 117904. [CrossRef] [PubMed]

63. Hu, B.; Li, Y.; Jiang, L.; Chen, X.; Wang, L.; An, S.; Zhang, F. Influence of microplastics occurrence on the adsorption of 17ß-estradiol in soil. J. Hazard. Mater. 2020, 400, 123325. [CrossRef]

64. Zhang, C.; Lei, Y.; Qian, J.; Qiao, Y.; Liu, J.; Li, S.; Dai, L.; Sun, K.; Guo, H.; Sui, G.; et al. Sorption of organochlorine pesticides on polyethylene microplastics in soil suspension. Ecotoxicol. Environ. Safety 2021, 223, 112591. [CrossRef]

65. Lara, L.Z.; Bertoldi, C.; Alves, N.M.; Fernandes, A.N. Sorption of endocrine disrupting compounds onto polyamide microplastics under different environmental conditions: Behaviour and mechanism. Sci. Total Environ. 2021, 796, 148983. [CrossRef] [PubMed]

66. Pérez-Madrid, A.; Rubí, J.M.; Mazur, P. Brownian motion in the presence of a temperature gradient. Phys. A Stat. Mech. Its Appl. 1994, 212, 231-238. [CrossRef]

67. Hazarika, S.; Ahmed, S. Brownian motion and thermophoresis behavior on micro-polar nano-fluid-A numerical outlook. Math. Comput. Simul. 2022, 192, 452-463. [CrossRef]

68. Zhang, Y.; Zhou, G.; Yue, J.; Xing, X.; Yang, Z.; Wang, X.; Wang, Q.; Zhang, J. Enhanced removal of polyethylene terephthalate microplastics through polyaluminum chloride coagulation with three typical coagulant aids. Sci. Total Environ. 2021, 800, 149589. [CrossRef]

69. Lares, M.; Ncibi, M.C.; Sillanpää, M.; Sillanpää, M. Occurrence, identification and removal of microplastic particles and fibers in conventional activated sludge process and advanced MBR technology. Water Res. 2018, 133, 236-246. [CrossRef]

70. Shen, M.; Zhang, Y.; Almatrafi, E.; Hu, T.; Zhou, C.; Song, B.; Zeng, Z.; Zeng, G. Efficient removal of microplastics from wastewater by an electrocoagulation process. Chem. Eng. J. 2022, 428, 131161. [CrossRef]

71. Abbasi, S.; Zinatizadeh, A.A.; Mirghorayshi, M.; Zinadini, S.; McKay, T. Electrocoagulation technique for continuous industrial licorice processing wastewater treatment in a single reactor employing Fe-rod electrodes: Process modeling and optimization and operating cost analysis. J. Environ. Chem. Eng. 2021, 106686. [CrossRef]

72. Liu, X.; Yuan, W.; Di, M.; Li, Z.; Wang, J. Transfer and fate of microplastics during the conventional activated sludge process in one wastewater treatment plant of China. Chem. Eng. J. 2019, 362, 176-182. [CrossRef]

73. Chen, Z.; Zhao, W.; Xing, R.; Xie, S.; Yang, X.; Cui, P.; Lü, J.; Liao, H.; Yu, Z.; Wang, S.; et al. Enhanced in situ biodegradation of microplastics in sewage sludge using hyperthermophilic composting technology. J. Hazard. Mater. 2020, 384, 121271. [CrossRef] [PubMed]

74. Tang, Y.; Zhang, S.; Su, Y.; Wu, D.; Zhao, Y.; Xie, B. Removal of microplastics from aqueous solutions by magnetic carbon nanotubes. Chem. Eng. J. 2021, 406, 126804. [CrossRef] 